\title{
COMPARISON OF WATER HEATING BY SOLAR COLLECTORS AND PHOTOVOLTAIC PANELS
}

Imants ZIEMELIS, chief researcher, Latvia University of Agriculture Ulbroka Reseach Centre, Petera Str. 2-2, Jelgava, LV-3001, imants.ziemelis@1lu.lv (corespondin author)

Henriks PUTANS, researcher, Latvia University of Agriculture Ulbroka Reseach Centre, Institute Str.24-8, Ulbroka, Stopinu county, LV-2130, henriksooo@inbox.lv

Ilze PELECE, chief researcher, department of Physics Latvia University of Agriculture, Zemgale Str. 23, Ozolnieki, Ozolnieki county, LV-3018, Latvia; ilze.pelece@1lu.lv

Andrejs SNEGOVS, master student, Latvia University of Agriculture Ulbroka Reseach Centre, Uzvaras Str. 3-20, Jelgava, LV-3001, andrejs.snegovs@gmail.com

\begin{abstract}
Amount of presently mainly used fossil energy resources on the earth are limited and its impact on the earth environment is negative. Therefore, scientific research on replacing them with alternative energy like solar is important. Usually in practice, solar radiation for domestic water heating by solar collectors and production of electric energy by photovoltaic (PV) panels is used. Obtained by solar panels electric energy for water heating also can be use. The aim of the research is to make out the more preferable method for water heating by solar radiation particularly in weather conditions of Latvia. There are some advantages and disadvantages for each of them analyzed in the paper. Our research has shown that, at the same intensity of solar radiation, the efficiency of solar collectors is higher while the heated water temperature in the system's hot water tank is lower, and at higher ambient air temperature as well, but opposite to this, efficiency of PV panels is higher at lower ambient air temperature. Electricity produced by PV panels, using an electric resistance heaters heat water independently of its temperature. The amount of heat energy transferred from a solar collector by heat carrier to the hot water tank depends on the temperature difference between the heat carrier and heated water. The method of investigation corresponds to the goal of investigation, the effectivity of solar collectors and solar panels of different design and construction has analyzed in the paper.
\end{abstract}

Keywords: efficiency, solar collectors, solar panels, water heating.

\section{INTRODUCTION}

Technological development of humanity is depending on growing energy production and consumption. Amount of fossil energy resources mainly used at present is limited and they create a considerable burden for the earth environment. Therefore, the use of more friendly and sustainable energy, like solar, is important. Conversation of solar radiation energy into other forms of energy, mainly heat and electricity, has a long history. For production of hot water usually solar collectors are used, but for electricity - photovoltaic (PV) panels, of different constructions. At the same time the electricity, produced by PV panels, for water heating can be used directly also. As solar collectors, so PV panels can have large number of types, performance, quality, construction peculiarities and costs. The aim of the study is to analyze, and compare domestic water heating by solar collectors and PV panels in Latvia meteorological conditions, using the results of our many years theoretical and experimental investigation.

In an absorber of the collar collector, solar radiation energy transforms into heat energy and heats the heat transfer medium, which delivers that energy and heats water in the systems hot water tank. Only part of solar radiation striking the solar collector has converted into heat energy. The collector efficiency $\eta^{c}$ usually has calculated as:

where: $P_{c o l}-$ power of solar collector, $\mathrm{W}$;

$$
\eta^{c}=\frac{P_{c o l}}{P_{s} \cdot A}
$$

$P s$ - intensity of solar radiation, $\mathrm{W} / \mathrm{m}^{2}$;

$A$ - collectors surface area, $\mathrm{m}^{2}$.

Copyright (C) 2017 The Authors. Published by Aleksandras Stulginskis University. This is an open-access article distributed under the terms of the Creative Commons Attribution License (CC-BY 4.0), which permits unrestricted use, distribution, and reproduction in any medium, provided the original author and source are credited. 
It describes the relationship of produced by the collector heat energy $\left(P_{c o l}\right)$, to received solar irradiation $\left(P_{s}\right)$ energy (Peuser, 2002). The efficiency of solar collectors in large scale depends on the temperature difference $\Delta T$, between mean absorber temperature and ambient air temperature:

$$
\Delta T=T a b s-T a m b
$$

where: Tabs - mean absorber temperature, ${ }^{\circ} \mathrm{C}$;

Tamb - ambient temperature, ${ }^{\circ} \mathrm{C}$.

The produced by a flat plate solar collector heat energy $\left(P_{c o l}\right)$ can be calculate by transfigured Hottel-Uiller-Bliss equation (Peuser et al. 2002):

$$
P_{c o l}=A\left[P_{s} \cdot \eta_{\mathrm{o}}-K_{l}\left(T_{h}-T_{a m b}\right)\right]
$$

where: $\eta_{o}$ - collectors optical coefficient;

$K_{l}-$ collectors heat loss coefficient;

$T h$ - heat carrier temperature, ${ }^{\circ} \mathrm{C}$. radiation.

As it follows from formula (3), the efficiency of solar collector in large scale depends on the intensity of solar

The intensity of solar radiation depends on the latitude of the place. The main solar energy using countries, like India, China, Turkey, Brazil and others are in the latitudes less than $50^{\circ}$ (Pelece et al. 2017). Latitude of Latvia $57^{\circ}$.

As the deficiency of solar collectors is its complicated construction and high cost. They have heat inertia. In Latvia there seldom are days without clouds. When clouds screen the sun, the heat transfer medium in the collector system quickly cools down and does not heat the water in the system's hot water tank. When the sky becomes without clouds, due to the heat inertia it takes some time for heating up the heat transfer medium in the collector. Only when the temperature of the heat transfer medium exceeds the water temperature in the hot water tank, heating starts. There heat loses is taking place, particularly if the distance from the collector and hot water tank is large. Therefore, heat insulation has be used, which makes the construction more complicated and expensive.

The efficiency of solar collectors decreases, if the temperature difference between heats transfer medium in the collector system and water temperature in the hot water tank decreases, and decreases at lower ambient temperature also. The efficiency of solar collectors and panels can be increased around 1.4 times, using concentrators of collar radiation (Ziemelis et al. 2017), but it makes the appliance more complicated and expensive. The equipment for tracing the sun solar collectors usually has more complicated construction than for PV panels.

The efficiency of PV panels only slightly depends on the ambient air temperature and is higher at lower ambient temperature (Pelece et al. 2017). In the case of heating water by PV panels, heaters of electric resistance are used. They heat water independently of its temperature and electric cables do not need heat insulation. Transformation of electric energy into heat energy goes almost without any losses. The efficiency of solar panels $\eta^{p}$, like of solar collectors, expresses the relationship of produced by the panel electric energy $\left(P_{p a n}\right)$, to received solar irradiation $\left(P_{s}\right)$ and can be calculate as:

$$
\eta^{p}=\frac{P_{p a n}}{P_{S} \cdot A}
$$

The efficiency of PV panels depends on the type of material and technology used at its production, and is within the limits of 0.10-0.20, but for solar collectors it can reach up to 0.75, depending on design and material (Pelece et al. 2017).

\section{MATERIALS AND METHODS}

In Ulbroka Research Centre several constructions of solar collectors suitable for Latvia meteorological conditions have developed, theoretically and experimentally investigated and Latvian patents received. In order to design new solar collector constructions and to plan the work of solar collector systems and its location, meteorological parameters, like air temperature, relative humidity, intensity of solar radiation under any angle of incidence, had to be known (Kancevica ${ }^{1}$ et al. 2006). For that, a special device MD-4 (Latvia patent LV 14312 B) had created and used (Putans ${ }^{1}$ et al. 2011). For analyze of different parameters of solar collectors produced by industry and at Ulbroka Research Centre, diagram (Fig.1) had developed and used.

Using the device, MD-4 (Putans ${ }^{2}$ at al. 2011) during 2005-2007 ambient air temperature and solar radiation intensity striking stationary in midday perpendicularly to sun beams placed surface and interruptedly tracking the sun surface, in every 10 minutes had measured and recorded (Table 1). The mean values of every year received by each of surfaces solar energy $E_{s t}$ and $E_{t r}$ is calculated. Further, using these values amount of heat energy produced by a flat plate solar collector, which metal absorber has covered with black vanished color and having one and two glass covers, had calculated. The results has compared with the energy produced by solar collector, which absorber has covered with selective material. 
Table 1. Measured mean daily temperature and amount of solar radiation energy received by stationary under $40^{\circ}$ to horizon placed $\left(E_{s t}\right)$ and tracking the sun $\left(E_{t r}\right)$ surface in Ulbroka during 2005-2007

\begin{tabular}{|c|c|c|c|c|c|c|c|c|c|c|c|c|}
\hline \multirow[b]{2}{*}{ Month } & \multicolumn{4}{|c|}{ Mean daily temperature, $\mathrm{T}^{0} \mathrm{C}$} & \multicolumn{4}{|c|}{$\mathrm{E}_{\mathrm{st}}, \mathrm{kWh} / \mathrm{m}^{2}$} & \multicolumn{4}{|c|}{$\mathrm{E}_{\mathrm{tr}}, \mathrm{kWh} / \mathrm{m}^{2}$} \\
\hline & 2005 & 2006 & 2007 & Mean & 2005 & 2006 & 2007 & Mean & 2005 & 2006 & 2007 & Mean \\
\hline March & 2.6 & -1.5 & 6.6 & 2.6 & 111 & 127 & 95 & 111 & 139 & 157 & 122 & 139 \\
\hline April & 8.8 & 8.0 & 7.4 & 8.1 & 141 & 124 & 142 & 136 & 189 & 167 & 199 & 185 \\
\hline May & 14.0 & 13.9 & 15.1 & 14.3 & 148 & 167 & 162 & 159 & 215 & 247 & 231 & 231 \\
\hline June & 18.1 & 18.7 & 19.1 & 18.6 & 185 & 183 & 171 & 180 & 270 & 287 & 258 & 272 \\
\hline July & 21.3 & 23.2 & 18.8 & 21.1 & 179 & 204 & 147 & 176 & 270 & 316 & 215 & 267 \\
\hline August & 18.6 & 19.9 & 20.7 & 19.7 & 141 & 134 & 163 & 146 & 201 & 186 & 226 & 204 \\
\hline Septem. & 15.7 & 16.6 & 14.1 & 15.5 & 116 & 135 & 109 & 120 & 158 & 175 & 140 & 158 \\
\hline October & 9.3 & 10.8 & 8.5 & 9.5 & 97 & 52 & 57 & 69 & 117 & 61 & 67 & 81 \\
\hline $\mathrm{T} ; \Sigma$ & 13.5 & 13.7 & 13.8 & 13.7 & 1116 & 1126 & 1046 & 1096 & 1558 & 1598 & 1457 & 1538 \\
\hline
\end{tabular}

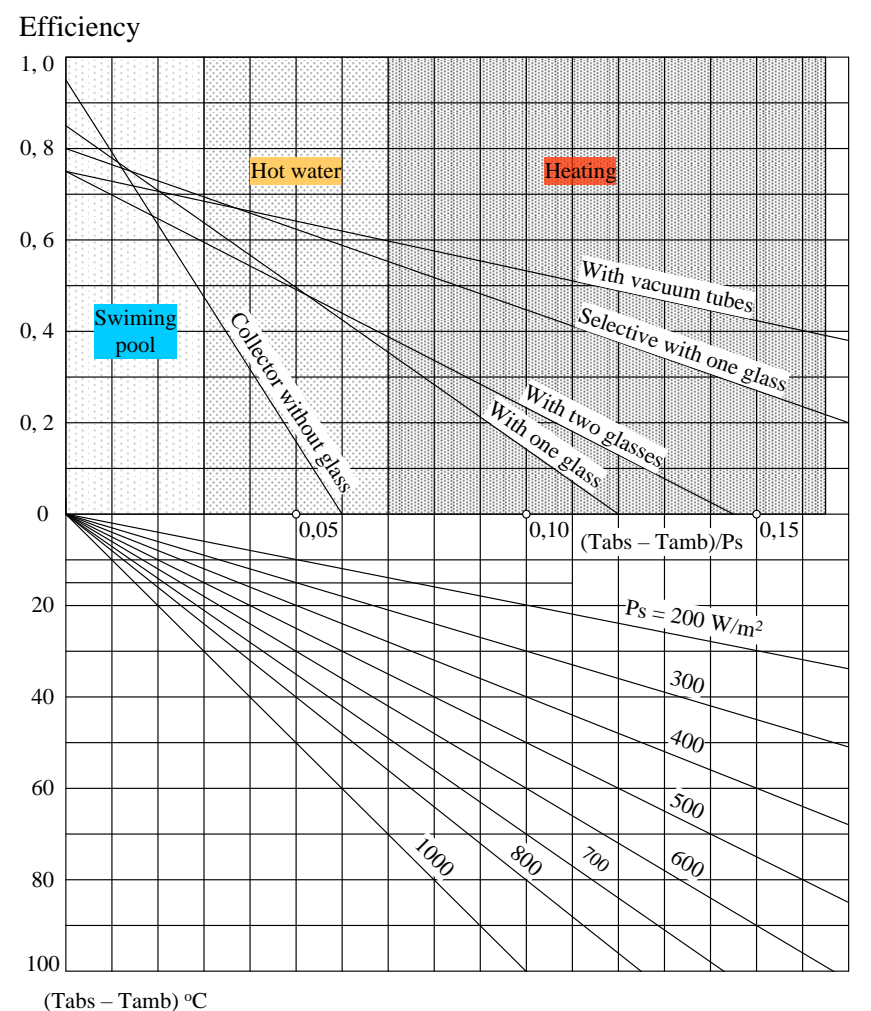

Figure1. Collectors efficiency dependent on its construction, the temperature difference between collector absorber and surroundings with differing intensity of radiation as parameter: $P_{s}$ - power of solar radiation, $\mathrm{W} / \mathrm{m}^{2} ; T_{a b s}-$ mean absorber temperature, ${ }^{\circ} \mathrm{C} ; T_{a m b}-$ ambient air temperature, ${ }^{\circ} \mathrm{C}$

Using the diagram (Fig.1), formulas (1), (2), (3), as well as values of $E_{s t}$ and $E_{t r}$ from Table 1, the energy produced by the inspected solar collectors at its absorber mean temperature $50^{\circ} \mathrm{C}$, its efficiency has calculated (Table 2). Obtained efficiency values with experimentally invested collectors efficiency has compared.

Table 2. Calculated amount of heat energy produced by solar collectors at absorber mean temperature $50^{\circ} \mathrm{C}$ and its efficiency

\begin{tabular}{|c|c|c|c|c|c|c|c|c|c|}
\hline & $\mathrm{E}_{\mathrm{st}}$, & $\mathrm{E}_{\mathrm{tr}}$, & \multicolumn{3}{|c|}{ Energy produced, $\mathrm{kWh} / \mathrm{m}^{2}$} & \multicolumn{3}{c|}{ Efficiency, \% } \\
\cline { 5 - 10 } Month & $\mathrm{kWh} / \mathrm{m}^{2}$ & $\mathrm{kWh} / \mathrm{m}^{2}$ & 1 glass & 2 glasses & Sel.st & Sel.tr & 1 glass & 2 glasses & Sel.st \\
\hline March & 111 & 139 & 21.9 & 37.6 & 42.8 & 54 & 19.8 & 33.9 & 38.6 \\
\hline April & 136 & 185 & 32.0 & 50.1 & 55.8 & 76 & 23.5 & 36.8 & 41.0 \\
\hline May & 159 & 231 & 47.8 & 66.4 & 71.7 & 104 & 30.1 & 41.8 & 45.1 \\
\hline June & 180 & 272 & 68.1 & 85.1 & 89.3 & 135 & 37.8 & 47.3 & 49.6 \\
\hline July & 176 & 267 & 68.6 & 84.6 & 88.5 & 134 & 39.0 & 48.1 & 50.3 \\
\hline Aug. & 146 & 204 & 53.0 & 67.5 & 71.2 & 100 & 36.3 & 46.2 & 48.8 \\
\hline Sept. & 120 & 158 & 34.7 & 49.1 & 53.3 & 70 & 28.9 & 40.9 & 44.4 \\
\hline Oct. & 69 & 81 & 12.1 & 22.1 & 25.5 & 30 & 17.5 & 32.0 & 37.0 \\
\hline Smean & 1096 & 1538 & 338.1 & 462.4 & 498.1 & 703 & 29.1 & 40.9 & 44.3 \\
\hline
\end{tabular}

The calculated efficiency of the collectors given in Table 2 is correct for the collectors of the inspected constructions and can change depending on the construction of the definite collector and weather conditions during its exploitation. 


\section{RESULTS AND DISCUSSION}

Results, experimentally stated and given in this paper has obtained in clear sunny days without clouds at the intensity of solar radiation about $1000 \mathrm{~W} / \mathrm{m}^{2}$, therefore they are comparable. It has stated that optimal declivity of fixed flat solar radiation receiving surface at Latvia latitude $\left(57^{\circ}\right)$ is $40^{\circ}$ from horizontal (Pelece et al. 2007). However, it is not necessary to consider it precisely, because even $10^{\circ}$ deflection influences the result insignificantly. At climatic conditions of Latvia the efficiency of solar collectors with steel plate absorber and steel tube heat exchanger is about 0.35 in summer month, but with copper plate absorber and copper tube heat exchanger, not less than 0.40 (Ziemelis ${ }^{1}$ et al. 2004). Latvian farmers often used to make solar collectors at their home conditions. Therefore, in such a case there is advice to use copper plate absorbers and copper tube heat exchangers for higher efficiency.

Two flat plate solar collectors with area of 1.4 and $4 \mathrm{~m}^{2}$ for the experimental investigation had implemented (Fig.2). Results showed that they were able to produce about $315-350 \mathrm{kWh}$ heat energy per $\mathrm{m}^{2}$ during the summer season - from May to October 2003. The efficiency of the collectors was within the limits of $0.35-0.40$ on the average.
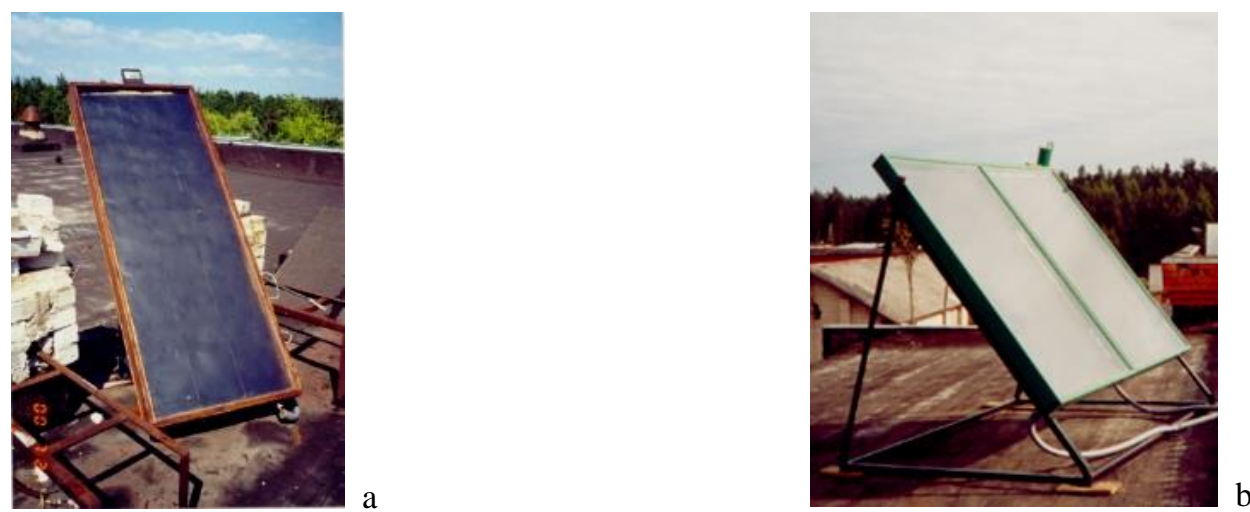

Figure 2. Flat plate solar collectors with aperture area $1.4 \mathrm{~m}^{2}$ (a) and $4.0 \mathrm{~m}^{2}(\mathrm{~b})$

On a large scale, the efficiency of a collector depends on the intensity of the consumption of hot water, that is, from the difference of the temperature in the hot water tank and heat transfer medium inlet temperature into the heat exchanger of the hot water tank (Ziemelis et al. 2004).

A solar collector with metal sheet absorber and canals in it had designed, produced and experimentally investigated (Ziemelis et al. 2007). The collector had anticipated mainly for low temperature water heating, for instance, in swimming pools or floor heating (Ziemelis et al. 2007), which efficiency is around 0.3.

The ordinary flat plate solar collectors are designed and constructed so, that only front side of the absorber receives solar radiation, but rear side has heat insulation. Using collectors when both sides are receiving solar radiation (Kancevica et al. 2006) it is possible to produce more heat energy from the same absorber area. In Ulbroka Research Centre has created solar collector irradiated from both sides (Fig.3).

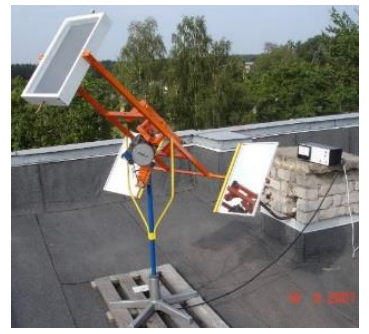

Figure 3. Solar collector with reflectors

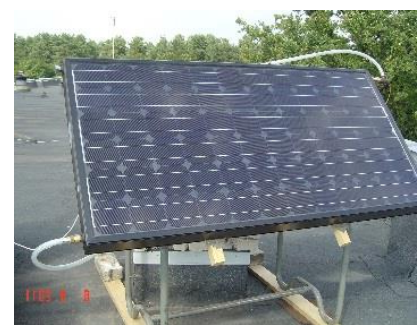

Figure 4. Hybrid photovoltaic-thermal solar collector MWPVT-1414

The ordinary flat plate solar collectors are designed and constructed so, that only front side of the absorber receives solar radiation, but rear side has heat insulation. Using tracking the sun solar collectors when both sides are receiving solar radiation (Kancevica et al.2007) it is possible to produce more heat energy from the same absorber area. The collector has solar radiation reflectors (mirrors) reflecting striking its solar beams on the rear side of the absorber, and the system is tracking the sun. There two reflectors are of the same size as the collector has, but another combination is possible also. Experimental investigation of the collector showed that the sun tracking solar collector produce 1.4-1.5 times more heat energy in comparison with a stationary working flat plate solar collector of the same size (Ziemelis et al. 2010).

The experimental investigation of hybrid classic photovoltaic-thermal solar collector MWPVT-1414 has carried out (Zagorska et al. 2012). There in one unit a photovoltaic panel has coupled with a flat plate solar collector (Fig.4). Therefore, the hybrid solar collector with working area $1.1 \mathrm{~m}^{2}$ is simultaneously conversing solar radiation into heat and 
electricity. The hybrid collector having solar radiation transfer coefficient $15 \%$ had stationary placed on the roof of a house and examined.

A special electric power-metering block had developed (Putans et al. 2010). The electric output had measured and in a certain period recorded in a $\mathrm{HOBO}$ type data logger. In addition, the amount of heat transfer medium circulating in the collector system and its temperature had metered and recorded. During the period of experimental investigation from August 6, 2011 until September 29, 2011 (55 days), the hybrid classic solar battery has produced $23.01 \mathrm{kWh}$ electric energy or 0.418 $\mathrm{kWh}$ per day on average. Produced power of heat was higher considerably all the period. Such combination is not advisable, because water temperature should be higher than $60^{\circ} \mathrm{C}$, which decreases the efficiency of a solar panel.

In comparison with traditionally solar energy using countries, in Latvia in summer the length of days reaches 17 hours and there is long path of the sun. At the same time, the maximum height of the sun above the horizon is only 56 degrees and during a year, the mean intensity of solar radiation is low. Often there the sky has covered by clouds. In winter, the length of the days is only around 7 hours with high nebulosity. Therefore, to use the solar energy in winter in Latvia is impossible.

A new construction of solar collector for Latvia, a semispherical collector has developed (Fig.5). The collector's absorber is made of one $\mathrm{mm}$ thick copper sheet as a dome. To the inner side of the bended copper sheet a heat exchanger, bended copper tube, has soldered. By means of a pump liquid heat transfer medium in running through the tube and transferring the heat from the absorber to the hot water tank. From outside the absorber has covered with transparent polyethylene terephthalate sheet, in order to protect the absorber from cooling. The base area of the collector is one $\mathrm{m}^{2}$. Theoretically, calculated amount of received energy of semi spherical surface with base area $1 \mathrm{~m}^{2}$ is only1.1 times less than that for flat one $\mathrm{m}^{2}$ tracking the sun surface (Pelece et al. 2010). Experimental investigation of the homemade semispherical solar collector has carried out from 1 August until 31 October 2009. Results show that it is less dependent on nebulosity. Regardless of 1.4 times smaller the energy gain, it is comparable with vacuum tube solar collector Vitasol 200 SD, made by industry.

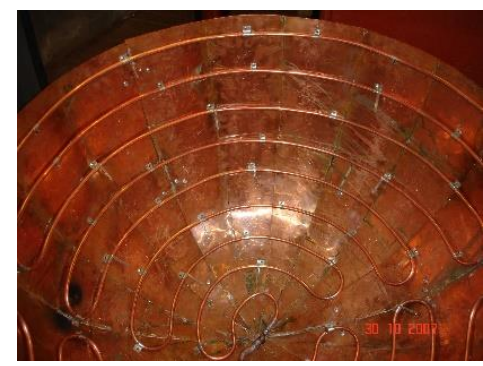

A parabolic solar collector of polished stainless steel sheet $\left(4 \mathrm{~m}^{2}\right)$, bended according to parabola has made (Fig.6). In the focus of the parabola, a metal tube - absorber has placed. The absorber by plastic tube has linked with the water pump and heat exchanger in the hot water tank. The collector has placed on a mobile platform with a hot water tank. The experimental investigation shows that it is quite fast water heating device and in sunny days at solar radiation intensity about $1000 \mathrm{~W} / \mathrm{m}^{2}$ the obtained in July 2010 heat power was around $1,2 \mathrm{~kW}$ and efficiency 0.60 .

For experimental investigation of solar battery panels Solet P6.60-WF-250 according to the scheme (Fig.7), two panels with surface area $3.25 \mathrm{~m}^{2}$ each had mounted on a dual axes automatic solar tracker ST44M2V4P (Fig.8). Measurements had carried out from August 1 until October 22, 2016. The power of the system at sunny October day reached $500 \mathrm{~W}$. At the intensity of solar radiation $P_{s}=1000 \mathrm{~W} / \mathrm{m}^{2}$ the efficiency of the system was 0.15 , that is about 5 times less than efficiency of a vacuum tube solar collector (Pelece et al. 2017).

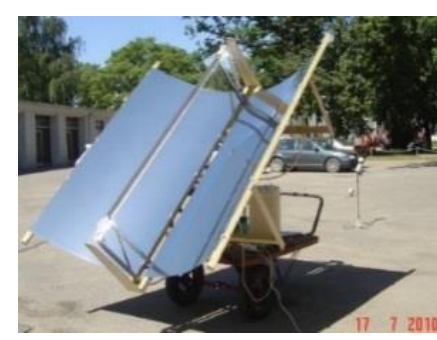

Figure 6. Parabolic solar collector

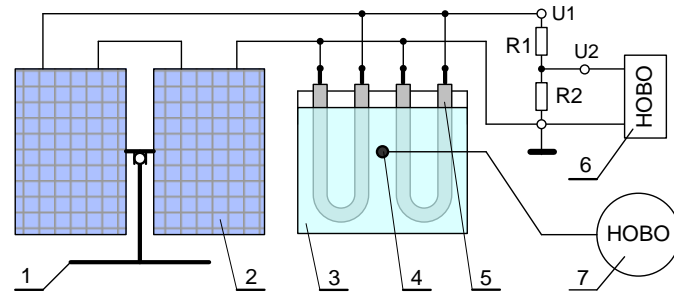

Figure 7. Scheme of experimental data registration: 1 - dual axis sun tracker ST44M2V4P; 2 - PV panels Solet P6.60-WF-250; 3 - hot water tank; 4 - data sensor; 5 - electric heater

$22 \Omega ; 6 ; 7$ - data registration HOBO H08-007-02

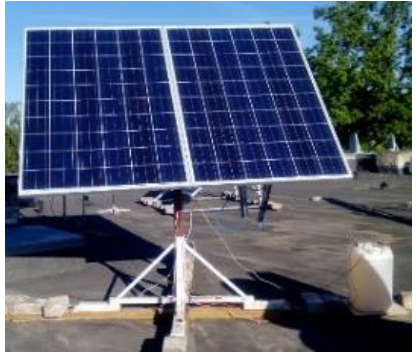

Figure 8. Dual axsis sun tracker ST44M2V4P with two solar panels

Solet P6.60-WF-250

From Fig. 1 it follows that for a simple collector with one transparent glass cover the maximum of the efficiency $\eta$ is about 0.84 , if $\Delta T=0$, that is, the mean absorber temperature is equal to ambient temperature. At the power of solar 
radiation $P_{s}=1000 \mathrm{~W} / \mathrm{m}^{2}$, the ratio $\Delta T / P_{s}=0.12$ and the efficiency of the collector $\eta^{\mathrm{c}}=0$. If $T_{a b s}-T_{a m b} / 1000=0.12$, the maximal temperature $T_{a b s}$ is $\left(\Delta T=T_{a b s}-T_{a m b}\right)=0.12 \cdot 1000=120^{\circ} \mathrm{C}$. It means the collector will interrupt production of heat energy at $120^{\circ} \mathrm{C}$. If the power of solar radiation will decrease, the obtained temperature will decrease also. If the solar power $P_{s}=500 \mathrm{~W} / \mathrm{m}^{2}$ (Fig.1), the maximal temperature will be $60^{\circ} \mathrm{C}$. For the collector with vacuum tubes the ratio $\Delta T$ / $P_{s}=0-0.17$ and the efficiency is from 0.38 up to 0.75 and the maximum of absorbers temperature $T_{a b s}$ at $P_{s}=1000 \mathrm{~W} / \mathrm{m}^{2}$ will be $T_{a b s}=0.17 \cdot 1000=170^{\circ} \mathrm{C}$.

\section{CONCLUSIONS}

1. Technically, it is possible to heat water by solar collectors and solar panels.

2. Efficiency of solar collectors at water heating depends on its design, construction, materials, ambient air temperature, intensity of solar radiation, and is $0.3-0.6$, but solar panels $0.1-0.15$.

3. If solar radiation is striking solar collectors or panels working surface perpendicularly all the time, its efficiency is 1.3-1.5 times higher, therefore solar trackers have to be used, but they heighten the price of the appliance.

4. Construction and exploitation of solar collectors of every type is more complicated than solar panels are.

5. PV panels do not have moving components.

\section{REFERENCES}

1. Kancevica, L., Putans, H., Putans, A., Ziemelis, I. 2006. Analysis of meteorological parameters for development of solar collectors. Proceedings of the $5^{\text {th }}$ International Scientific Conference "Engineering for Rural Development", pp. 117-180, Latvia University of Agriculture.

2. Kancevica' L., Putans, H., Ziemelis, I. 2006. Mirror-collector for solar water heating. Proceedings of the $5^{\text {th }}$ International Scientific Conference "Engineering for Rural Development", pp. 181-185, Latvia University of Agriculture.

3. Kancevica, L., Putans, h., Ziemelis, I., Putans, A., Jesko, Z. 2007. Solar energy collector device with reflectors. Latvia patent LV 13549.

4. Pelece, I., Iljins, U., Ziemelis, I., Ziemelis, E. 2007. Theoretical calculation of energy received by solar collectors. Proceedings of the $6^{\text {th }}$ International Scientific Conference "Engineering for Rural Development 2007", pp. 29-34, Latvia University of Agriculture.

5. Pelece, I., Putans, H., Ziemelis, I., Kancevica, L. 2017. Water heating with tracking the sun solar batteries. Proceedings of the 16th International Scientific Conference "Engineering for Rural Development 2017", pp. 761-766, Latvia University of Agriculture. https://doi.org/10.22616/ERDev2017.16.N154

6. Peuser, F.A., Remmers, K.H., Schnauss, M. 2002. Solar Thermal Systems. Solarpraxis, Berlin.

7. Putans, H., Ziemelis, I., Kancevica, L., Putans, A. 2008. Tracking the sun solar energy collector device with reflectors. Latvia patent LV 13713.

8. Putans H., Putans A., Iljins U., Pelece I., Zagorska V., Kancevica L., Ziemelis I., Jesko Z. 2010. Solar battery power registration device. Latvia patent LV 14165.

9. Putans ${ }^{1}$ H., Zagorska V., Ziemelis I., Jesko Z. 2011. Research on solar energy collectors with cell polycarbonate absorber. Proceedings of the $8^{\text {th }}$ International Scientific and Practical Conference "Environment. Technology. Resources", Vol. 1, pp. 213-219. Rezekne, Latvia.

10. Putans ${ }^{2}$ H., Zagorska V., Ziemelis I., Kancevica L., Jesko Z. 2011. Mobile meteorological date measuring and registration device. Latvia patent LV 14312.

11. Zagorska V., Ziemelis I., Kancevica L., Putans, H. 2012. Experimental investigation of photo-thermal hybrid solar collector. Proceedings of the International Scientific Conference “Agronomy Research”, Vol. 10, pp. 227-234, Estonia University of Agriculture.

12. Ziemelis ${ }^{1}$ I., Iljins U., Skele A. 2004. The choice of efficiency of a flat plate solar collector. Proceedings of the International Scientific Conference "Information technologies and telecommunications for rural development 2004", pp. 117-124, Latvia University of Agriculture.

13. Ziemelis ${ }^{2}$ I., Iljins U., Putans A. 2004. Investigation and experience of water heating by solar energy in Latvia. Proceedings of the $9^{\text {th }}$ International Conference "Ecologycal energy resources in agriculture", pp. 50-53. Raudondvaris, Lithuania.

14. Ziemelis ${ }^{1}$ I., Kancevica L., Ziemelis E., Jesko Z. 2007. Comparative studies of varied flat plate solar collector structures. Proceedings of the International Scientific Conference "Technical and technological progress in agriculture", Vol. 12, pp. 174-177. Raundondvaris, Lithuania.

15. Ziemelis² I., Kancevica L., Jesko Z., Ziemelis E., Putans A. 2007. Flat solar collector absorber with canals. Latvia patent LV 13516.

16. Ziemelis I., Putans H., Kancevica L. 2010. Investigation of solar collector irradiated from both sides. Agronomy Research. Special issue1. Biosystems engineering, Vol. 8, pp. 280-286. Tartu, Estonia.

17. Ziemelis I., Putans H., Pelece I., Snegovs, A. 2017. Comparative investigation of fixed and tracking the sun solar photovoltaic panels. Proceedings of the 16th International Scientific Conference "Engineering for Rural Development 2017", pp. 540-545, Latvia University of Agriculture. https://doi.org/10.22616/ERDev2017.16.N107 